\title{
Natural selection and the heritability of fitness components
}

\author{
Timothy A. Mousseau and \\ Derek A. Roff
}

\begin{abstract}
Department of Biology, McGill University, 1205 Avenue Dr. Penfield, Montreal, Quebec, Canada H3A 1 B1.
\end{abstract}

\begin{abstract}
The hypothesis that traits closely associated with fitness will generally possess lower heritabilities than traits more loosely connected with fitness is tested using 1120 narrow sense heritability estimates for wild, outbred animal populations, collected from the published record. Our results indicate that life history traits generally possess lower heritabilities than morphological traits, and that the means, medians, and cumulative frequency distributions of behavioural and physiological traits are intermediate between life history and morphological traits. These findings are consistent with popular interpretations of Fisher's $(1930,1958)$ Fundamental Theorem of Natural Selection, and Falconer (1960, 1981), but also indicate that high heritabilities are maintained within natural populations even for traits believed to be under strong selection. It is also found that the heritability of morphological traits is significantly lower for ectotherms than it is for endotherms which may in part be a result of the strong correlation between life history and body size for many ectotherms.
\end{abstract}

\section{INTRODUCTION}

The fundamental theorem of natural selection states: "The rate of increase in fitness of any organism at any time is equal to its genetic variance in fitness at that time" (Fisher, 1930). Fisher's theorem is axiomatic to much of current evolutionary research. It has been variously interpreted but is generally construed to imply that traits that have been closely and consistently associated with fitness will exhibit low additive genetic variances as a result of natural selection (e.g., Hegmann and Dingle, 1982; Lynch and Sulzbach, 1984; Riddel et al., 1981). However, the validity of the fundamental theorem is dependent upon many assumptions that may not usually be met by natural populations (e.g., population equilibrium, weak selection, constancy of genotypic fitnesses over time, and independence of genotypic frequencies) (Charlesworth, 1987). The maintenance of low additive genetic variance has also been inferred to imply low heritability (in the narrow sense); "On the whole, characters with the lowest heritabilities are those most closely connected with fitness, while characters with the highest heritabilities are those that might be judged on biological grounds to be the least important as determinants of natural selection." (Falconer, 1960, 1981.) The most exten- sive compilation of data in support of this view is that presented in table 10.1 of Falconer (1981). However, these data are rather few and derived primarily from domestic animals, which may be partly inbred. Extension to wild, outbred organisms may be erroneous.

It is possible that some significant amount of additive genetic variance can be maintained within natural populations, even for characters tightly connected to fitness; possible mechanisms include mutation (Lande, 1976; Turelli, 1984), heterozygote advantage (Falconer, 1981), frequency dependence (Bulmer, 1980), fluctuating environments (Ewing, 1979) and migration (Felsenstein, 1976). In addition, zero additive genetic variance in fitness is consistent with positive heritability estimates of fitness components when there exists negative genetic correlations between components (Rose and Charlesworth, 1981).

It is in response to the importance the views of Fisher $(1930,1958)$ and Falconer $(1960,1981)$ have reached in the ecological literature, and the concurrent lack of rigorously examined empirical support for these views, that we have undertaken the compilation, analysis, and interpretation of the extensive quantity of data concerning genetic variation within natural populations now available from the published record. 
In this paper we address two questions: (a) What is the heritability of traits closely associated with fitness? Do traits that are directly connected to fitness tend to have lower heritabilities than traits more loosely associated with fitness as proposed by Falconer $(1960,1981)$ and suggested by Fisher $(1930,1958)$ ? If we find this to be not the case a serious reevaluation of current evolutionary thinking would be necessary. (b) Do patterns of genetic variability change from taxa to taxa? If so, this might suggest phylogenetically determined constraints upon rates of evolution.

\section{The data set}

The data set comprises 1120 narrow sense heritability estimates collected from 140 sources, representing 75 species. Heritability estimates for the Drosophila genus were excluded from the present study as they are treated elsewhere (Roff and Mousseau, 1987). The only prerequisite for inclusion in the data set was that the heritability estimate be derived from a wild, outbred stock; so as to avoid biases potentially introduced through our literature reviewing process, the data were in no other way screened or selected. This compilation is the most extensive of its kind but is not exhaustive. A list of the sources, divided according to species, is given in an appendix.
For the purposes of analysis we define four categories of traits: (a) behavioural traits, (b) life history traits, (c) morphological traits, and (d) physiological traits. We have restricted the term "life history trait" to those characters that are directly and invariably connected to fitness. Some examples of life history traits are fecundity, viability, survival, and development rate. Morphological traits include body size, wing size, and other metric characters. Behavioural and physiological traits are much less widely reported than life history or morphological traits. Examples of behavioural traits are alarm reaction, activity level, and sensitivity to conditioning. Physiological traits include oxygen consumption, resistance to heat stress, and body temperature.

The composition of the data set, divided according to trait type and taxonomic assignment is presented in fig. 1. A total of 341 life history traits, 570 morphological traits, 104 physiological traits, and 105 behavioural traits are represented within the data set. Alternatively, there are 414 heritability estimates for invertebrates, 460 estimates for ectothermic vertebrates (reptiles, amphibians, and fishes), and 246 estimates for endothermic vertebrates (birds and mammals). These taxonomic designations reflect divisions between groupings of biological and ecological significance, and an attempt to maintain statistically sufficient sample sizes within each grouping.

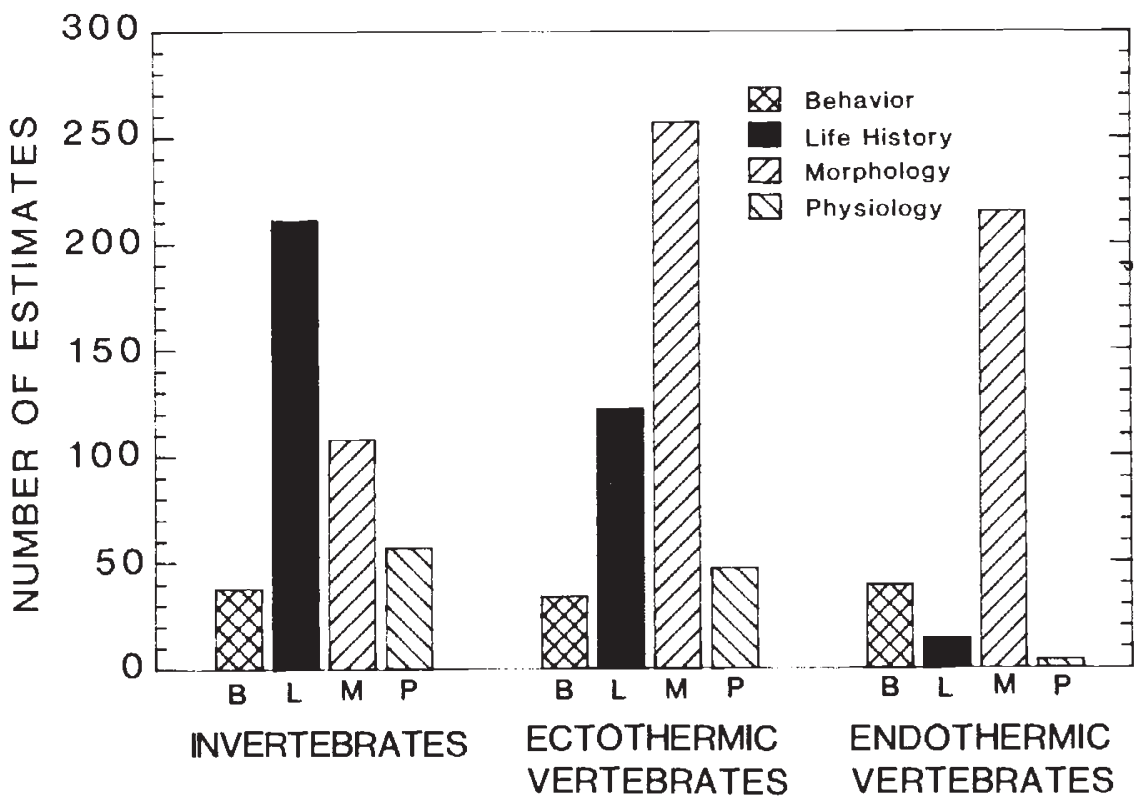

Figure 1 The number of reported heritability estimates grouped according to trait type and taxonomic assignment. 


\section{The analysis}

\section{Methods of heritability estimation}

Are estimates of additive genetic variances seriously biased by the methods of calculation? It is widely accepted that published estimates of quantitative genetic parameters are seldom free from biases introduced by inbreeding, assortative mating, dominance, maternal effects, non-additive genetic variances, and non-random sampling of genotypes from natural populations etc. (MitchellOlds and Rutledge, 1986). Given the heterogeneous nature of our data set, we commence this investigation with a comparison of heritability estimates generated using different methods of calculation. The outcome of this examination will dictate whether it is necessary to include the method of estimation as a factor in the analyses to follow.

The most commonly employed methods of heritability estimation within our data set are the parent-offspring regression $(n=341)$ and the fullsib correlation $(n=463)$ designs. The realised $(n=$ $133)$ and half-sib $(n=176)$ designs are much less frequently utilized and as a result, insufficiently represented for the analyses to follow.

Theory (Falconer, 1981) predicts that within a given population, for a given trait, estimates generated using the full-sib design will usually be higher or equal to those produced using the parentoffspring method. This results primarily from the covariance of full sibs being inflated by environmental variance between families and by dominance variance (Falconer, 1981).

The simplest and most convincing manner in which to approach this question is to compare heritability estimates calculated using different methods for the same character within a given population. This approach avoids problems related to the sensitivity of heritability estimates to differences between populations in environmental conditions, past and present (Falconer, 1981).

Table 1 list 33 paired heritability estimates for a variety of characters, obtained from 11 independent studies, for 9 species. We found that on average, the full-sib design produced estimates that were greater by 0.073 than those obtained using the parent-offspring regression method. In addition, full-sib estimates were higher than parentoffspring estimates for 20 of the 33 cases. However, the results of a paired comparison $t$-test, a Wilcoxon's signed rank test, and a simple sign test revealed no significant differences between estimates generated using these two methods (table 1).
The relationship between pairs of estimates can be described by the following linear regression equation:

$$
\begin{gathered}
F S=0.72( \pm 0.15) P O+0.23( \pm 0.09), \quad r=0.65, \\
M S E=0.064, \quad t=4.74, \quad p<0.0001
\end{gathered}
$$

where $F S$ and $P O$ are the estimates derived from the full-sib and parent-offspring methods, respectively (fig. 2). Since we are concerned with the functional relationship between heritability estimates generated using the full-sib and parentoffspring methods, and the errors of estimation are roughly comparable for both methods, it is appropriate that we determine the slope of the functional regression using Ricker's (1973) formula:

$$
v=b / r
$$

where $v$ is the slope of the functional regression, $b$ is the slope obtained using an ordinary linear regression, and $r$ is the correlation coefficient of the relationship. Ricker's (1973) formula is used because simple least-squares linear regressions will tend to seriously underestimate the slope (when $r$ is $<1)$ if the abscissal $(X)$ observations are subject to natural variability of the same magnitude as the $Y$ observations. We find that once corrected, the slope describing the functional relationship between full-sib and parent-offspring estimates equals $1 \cdot 10$, which is not significantly different from unity.

Even if the lack of statistical significance found between estimates generated using different methods of calculation were primarily due to insufficient data, the bias that might be introduced is sufficiently small ( $<10$ per cent) to justify the pooling of full-sib and parent-offspring estimates. In any case, the various estimates (full-sib, half-sib, parent-offspring, and realised) were roughly evenly represented in the different trait groupings.

Heritability estimates are frequently reported without standard errors; only 738 of the 1120 estimates collected for this study included standard errors. We found the relationship between the standard error and the heritability estimate to be:

$$
\begin{aligned}
& S E=0.172( \pm 0.014) h^{2}+0.088( \pm 0.007), \\
& r=0.41, \\
& M S E=0.14, \quad t=12, \quad p<0.0001 .
\end{aligned}
$$

Although heritability estimates frequently possess large standard errors, an analysis of variance upon the residuals of the above relationship found no significant difference between the standard errors 
Table 1 Within study comparisons of heritability estimates calculated using the parent-offspring (PO) and full-sib (FS) methods of analysis. Paired comparison $t$-test: $D=0.073$, S.E. $=0.046, t=1 \cdot 71, p=0 \cdot 10$. Wilcoxon's signed rank test: sum of negative ranks $=-193$, sum of positive ranks $=368, p=0 \cdot 120$. Sign test: $p=0 \cdot 15$

\begin{tabular}{|c|c|c|c|c|c|}
\hline Species & Character & FS & $\mathrm{PO}$ & $\mathrm{FS}-\mathrm{PO}$ & Reference \\
\hline \multicolumn{6}{|c|}{ Invertebrates } \\
\hline \multirow[t]{2}{*}{ Apis mellifera } & chill coma & 0.37 & $0 \cdot 15$ & $0 \cdot 22$ & Hillesheim, 1984 \\
\hline & $\mathrm{O}^{2}$ consumption & 0.41 & $0 \cdot 13$ & $0 \cdot 28$ & Hillesheim, 1984 \\
\hline \multirow[t]{2}{*}{ Eurytemora affinis } & temperature & $0 \cdot 20$ & $0 \cdot 11$ & 0.09 & Bradley, 1982 \\
\hline & tolerance & $0 \cdot 80$ & 0.76 & 0.03 & Bradley, 1982 \\
\hline \multirow[t]{2}{*}{ Eurytemora herdmani } & length & 0.48 & $0 \cdot 12$ & 0.36 & McLaren, 1976 \\
\hline & length & 0.65 & $0 \cdot 54$ & $0 \cdot 11$ & McLaren, 1976 \\
\hline \multirow[t]{2}{*}{ Gryllus firmus } & wing length & 0.64 & 0.74 & $-0 \cdot 1$ & Roff, $1986 b$ \\
\hline & wing length & 0.62 & 0.40 & 0.22 & Roff, $1986 b$ \\
\hline Pseudocalanus & length & 0.92 & 0.98 & -0.06 & McLaren and Corkett, 1978 \\
\hline \multirow[t]{2}{*}{ Tribolium castaneum } & fecundity & $0 \cdot 38$ & $0 \cdot 36$ & 0.02 & Orozco, 1976 \\
\hline & fecundity & 0.35 & $0 \cdot 30$ & 0.05 & Orozco, 1976 \\
\hline \multicolumn{6}{|c|}{ Amphibians } \\
\hline \multirow[t]{2}{*}{ Plethodon cinereus } & \# of vertebrae & 0.57 & 0.61 & -0.04 & Highton, 1960 \\
\hline & & & Bird & & \\
\hline \multirow[t]{14}{*}{ Geospiza fortis } & weight & 0.78 & 0.91 & $-0 \cdot 13$ & Boag, 1983 \\
\hline & wing length & 0.42 & 0.84 & -0.42 & Boag, 1983 \\
\hline & tarsus length & 0.32 & 0.71 & -0.39 & Boag, 1983 \\
\hline & bill length & $1 \cdot 11$ & 0.65 & 0.46 & Boag, 1983 \\
\hline & bill depth & $1 \cdot 12$ & 0.79 & $0 \cdot 33$ & Boag, 1983 \\
\hline & bill width & 0.99 & 0.90 & 0.09 & Boag, 1983 \\
\hline & bill length & 0.64 & 0.35 & 0.29 & Boag, 1983 \\
\hline & weight & 0.80 & 0.91 & $-0 \cdot 11$ & Boag and Grant, 1978 \\
\hline & wing length & 0.65 & 0.63 & 0.02 & Boag and Grant, 1978 \\
\hline & tarsus length & $0 \cdot 27$ & 0.42 & $-0 \cdot 15$ & Boag and Grant, 1978 \\
\hline & bill length & $1 \cdot 34$ & 0.85 & 0.49 & Boag and Grant, 1978 \\
\hline & bill depth & $1 \cdot 41$ & 0.90 & 0.51 & Boag and Grant, 1978 \\
\hline & bill width & 0.99 & $1 \cdot 03$ & $-0 \cdot 04$ & Boag and Grant, 1978 \\
\hline & bill length & 0.78 & 0.41 & 0.37 & Boag and Grant, 1978 \\
\hline \multirow[t]{7}{*}{ Geospiza scandens } & weight & 0.35 & 0.58 & -0.23 & Boag, 1983 \\
\hline & wing length & 0.35 & $0 \cdot 12$ & $0 \cdot 23$ & Boag, 1983 \\
\hline & tarsus length & 0.88 & 0.92 & -0.04 & Boag, 1983 \\
\hline & bill length & $0 \cdot 30$ & $0 \cdot 32$ & -0.02 & Boag, 1983 \\
\hline & bill depth & 0.56 & $0 \cdot 14$ & 0.42 & Boag, 1983 \\
\hline & bill width & 0.56 & $0 \cdot 34$ & 0.22 & Boag, 1983 \\
\hline & bill length & 0.06 & 0.60 & -0.54 & Boag, 1983 \\
\hline
\end{tabular}

associated with estimates generated using the fullsib and parent-offspring methods of calculation $(F=1 \cdot 7, p>0 \cdot 2, n=659)$.

The above results suggest that there is no apparent bias introduced to the data set by the method of heritability estimation; Roff and Mousseau (1987) obtained a similar result for Drosophila when comparing parent-offspring estimates with half-sib and realised estimates. The method of heritability estimation will not be considered further in this study.

\section{Heritability and fitness}

Classical theory (e.g., Falconer, 1960; Fisher, 1930) predicts that traits closely associated with fitness will have low heritabilities while more distantly related traits should have higher heritabilities. If this is indeed the case for natural populations we would expect life history traits to possess, on average, lower heritabilities than morphological traits. It is more difficult to predict a priori the relationship between fitness and behavioural and physiological traits. Falconer's compilation (1981, table 10.1, p. 150) would suggest that physiological traits are intermediate between life history traits and morphological traits with respect to average heritabilities. It has been proposed that many behavioural traits will be under strong stabilising selection (Lee and Parsons, 1968), and as a result, possess low heritabilities. It seems only reasonable to suppose that traits such as food conversion 


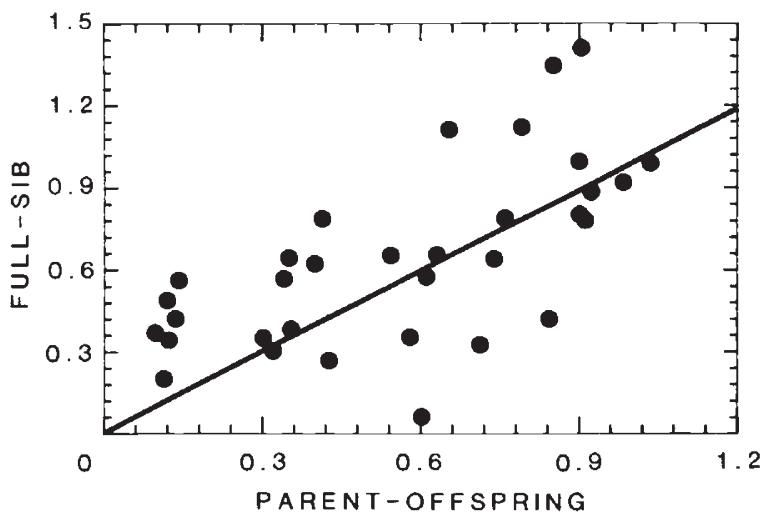

Figure 2 A scatterplot showing the relationship between paired heritability estimates generated using full-sib correlation and parent-offspring regression methods of estimation for the same population $(r=0.62)$. The slope of the plotted line represents a $1: 1$ correspondence.

efficiency and mating propensity are more closely connected to fitness than morphological traits. However, this assumption must be viewed cautiously as fecundity and development time in ectotherms are tightly correlated with body size, a morphological trait (Kusano, 1982; Peters, 1983; Roff, 1981, 1984, 1986a). For this reason we do not make any predictions concerning the ranking of heritabilities of morphology, behaviour, and physiology, but rather, use the data to discern whatever pattern might exist.

All analyses were performed using an IBM PC; complete descriptions of the statistical tests employed can be found in Sokal and Rohlf (1981). The use of non-parametric statistics (e.g., the Kolmogorov-Smirnov test, and the KruskalWallis test) have been emphasized in our analyses in order to avoid the violation of assumptions associated with the use of more traditional parametric statistics (e.g., normality, homogeneity of variances).

Our analysis of the data has been arranged in a hierarchical manner, organised into four progressively finer scaled lines of investigation: (a) The analysis of the entire data set. (b) The analysis of median heritability values of each character, for a given species. This approach will allow the elimination of biases in the data set due to overrepresentation of particular characters and species, and will negate the influence held by outliers. (c) The analysis of random subsamples of the data set. The objective of this approach is to assess the stability of any patterns that have emerged from the previous analyses. (d) The paired comparison of life history and morphological traits derived from identical populations and studies.

\section{The entire data set}

At this resolution, our analysis is directed towards the illumination of gross patterns of variation. We ignore potential biases introduced via the overrepresentation of certain species and characters, and the effect of outliers.

Figure 3 shows the cumulative distribution frequencies of the four trait groupings; table 2 lists descriptive statistics and the results of Kolmogorov-Smirnov tests upon paired comparisons of each of the cumulative distributions. The results indicate that life history traits are generally much lower than morphological traits, and that behavioural and physiological traits tend to fall in the middle. This pattern is consistent with the observed means, medians, and cumulative distribution frequencies, and is supported by the results of a one-way ANOVA $(F=39 \cdot 7, p<$ $0 \cdot 0001, \mathrm{df}=1119)$ and a Kruskal-Wallis test $(H=$ 106, $p<0.0001, n=1120$ ). Furthermore, the ANOVA and Kruskal-Wallis tests yield significant statistics even when morphological traits are excluded $(F=5 \cdot 0, p<0.007, \quad \mathrm{df}=549 ; \quad H=$ $7 \cdot 22, p<0 \cdot 027, n=550)$.

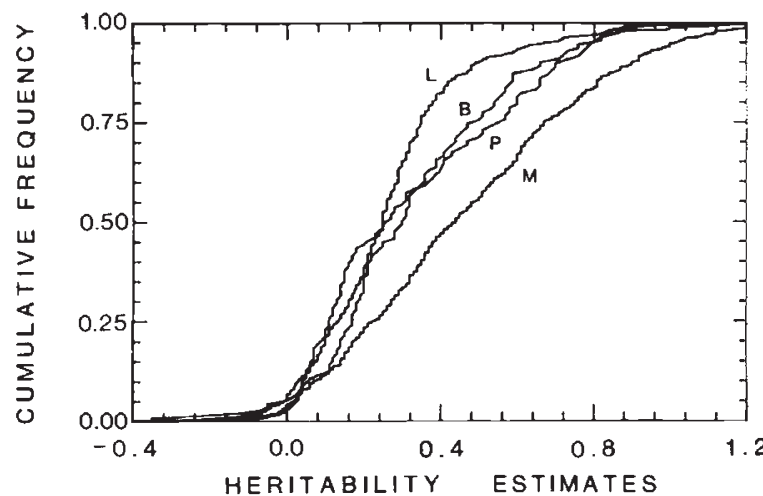

Figure 3 The cumulative frequency distributions of the four trait categories ( $\mathrm{L}=$ life history, $\mathrm{B}=$ behaviour, $\mathrm{P}=$ physiology, and $M=$ morphology) for the entire data set. Note that data points are joined by straight lines.

\section{The analysis of median values}

Frequently, multiple heritability estimates have been reported for a given character and species. For the following analysis we have confined our interest to the median of the range in estimates reported for each character of each species.

Figure 4 shows the cumulative distribution frequencies of the four trait categories. A summary of descriptive statistics and the results of Kolmogorov-Smirnov tests upon the paired comparisons of each distribution is given in table 3 . 


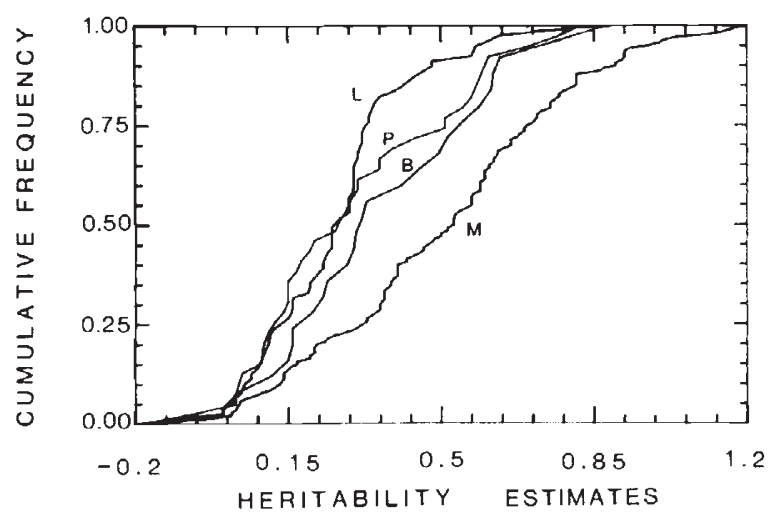

Figure 4 The cumulative frequency distributions of the four trait categories ( $\mathrm{L}=$ life history, $\mathrm{B}$ =behaviour, $\mathrm{P}=$ physiology, and $\mathrm{M}=$ morphology) for median heritability values for eacb character of each species. Note that data points are joined by straight lines.

The results of this analysis are qualitatively similar to those obtained for the larger data set; the rankings of the means, medians, and cumulative distributions are identical. The main difference resulting from the use of medians is the lack of significance found by the Kolmogorov-Smirnov test upon comparisons between the cumulative distributions of life history traits and physiological and behavioural traits. Given that the rankings and absolute values are very similar to those obtained for the larger data set, we conclude that this lack of significance is primarily due to the drastically reduced sample sizes and the conservative nature of the Kolmogorov-Smirnov test. The results of a Kruskal-Wallis test and a one-way ANOVA indicate that trait is indeed an important factor governing the patterns of variance within the median data set $(H=47 \cdot 4, p<0.0001, n=283 ; \quad F=18 \cdot 7, p<$ $0.0001, \mathrm{df}=282$ ), but only when morphological traits are included in the analysis (without mor- phology: $H=3 \cdot 94, p>0 \cdot 13, n=142 ; F=2 \cdot 83, p>$ $0 \cdot 06, \mathrm{df}=140$ ).

\section{Random sampling of the data set}

For this analysis, as an alternative to using median values for a character, a representative estimate was selected at random. For example, a total of ten heritability estimates for age at maturity were collected for the rainbow trout Salmo gairdneri. Of those 10 estimates, one was randomly chosen to represent this character, for this species. This process was repeated for all characters and species with multiple estimates to generate a randomly selected subset of the larger data set. The entire process was repeated to provide 25 such subsets and all tests were performed individually upon each subset. As with the use of medians, this approach eliminates biases due to the overrepresentation of particular characters and species.

We found that generally, the results obtained from the random sampling of the data set were statistically similar to those found using median values (table 4 ). In only one out of 150 comparisons did the results contradict those obtained using medians. Overall, we conclude that the pattern of trait rankings derived from the median data set is robust to the variance contained within the larger data set.

\section{The paired comparison of fitness and non- fitness traits}

The objective of this analysis was to make comparisons of traits independently of the species and study from which they were derived. To meet this objective we have collected data from 10 sources and 9 species where estimates for life history and morphological traits have been reported for the same population (table 5). We have confined our

Table 2 Summary of descriptive statistics and Kolmogorov-Smirnov tests $\left(D_{\text {max }}\right)$ for all data

\begin{tabular}{lllll}
\hline & Life history & Physiology & Behaviour & Morphology \\
\hline$n$ & 341 & 104 & 105 & 570 \\
$\bar{x}$ & 0.262 & 0.330 & 0.302 & 0.461 \\
S.E. & 0.012 & 0.027 & 0.023 & 0.004 \\
median & 0.250 & 0.262 & 0.280 & 0.428 \\
$D_{\text {max }}$ & & & & \\
Physiology & 0.199 & & & \\
Behaviour & $p<0.0003$ & & & \\
Morphology & 0.154 & 0.123 & & \\
& $p<0.04$ & $p>0.3$ & & \\
& 0.390 & 0.220 & 0.338 & \\
\hline
\end{tabular}


Table 3 Summary of descriptive statistics and Kolmogorov-Smirnov tests $\left(D_{\max }\right)$ for character medians

\begin{tabular}{lllll}
\hline & Life history & Physiology & Behaviour & Morphology \\
\hline$n$ & 79 & 39 & 25 & 140 \\
$\bar{x}$ & 0.265 & 0.308 & 0.374 & 0.511 \\
S.E. & 0.028 & 0.040 & 0.050 & 0.021 \\
median & 0.260 & 0.270 & 0.320 & 0.530 \\
$D_{\max }$ & & & & \\
Physiology & $0 \cdot 194$ & & & \\
Behaviour & $p>0.28$ & & & \\
Morphology & 0.298 & 0.199 & & \\
& $p>0.19$ & $p>0.9$ & & \\
& 0.562 & 0.373 & 0.366 & \\
\hline
\end{tabular}

focus to life history and morphological traits because this is the comparison of greatest concern, and also because there were insufficient data to examine the other trait categories. Where multiple estimates were reported for either of the trait types, the median value was used. The results do not differ if means are substituted for medians.

It was found that life history traits tended to possess lower heritabilities than morphological traits. The heritability of morphological traits was higher than life history traits in 11 of the 14 populations. The average difference between the two trait groupings was $0 \cdot 15$, with the results of a paired comparison $t$-test, a Wilcoxon's signed rank test, and a simple sign test statistically supporting the significance of this difference (table 5).

\section{Heritability and phylogeny}

In this section of the paper we address the question: Do patterns of heritability vary from taxa to taxa? It is apparent that there exist developmental constraints related to evolutionary history that may have led to differences between taxonomic groups with respect to the additive genetic variance of various characters. For example, it is well established that fecundity and body size are positively correlated in many ectothermic species (e.g., fish, spiders, salamanders, aquatic ectotherms), and that this correlation is insignificant or negative for birds and mammals (Kusano, 1982; Peters, 1983, p. 279; Roff, 1981, 1984, 1986a). This would suggest that morphological traits related to body size will possess lower heritabilities in ectothermic organisms than in endotherms.

In the following analysis we have examined patterns of heritability variation within four major phylogenetic groupings. Because of the need to maintain sample sizes sufficient for statistical analysis, we have limited our interest to the comparison of invertebrates versus vertebrates and ectotherms versus endotherms for life history and morphological traits.

Kolmogorov-Smirnov tests upon the cumulative distributions (fig. 5) indicate that ectotherms have lower heritabilities for morphological traits than do endotherms $\left(D_{\max }=0 \cdot 23, p<0 \cdot 0001\right)$. Thus result is reinforced by a Mann-Whitney U. test $(z=5 \cdot 65, p<0 \cdot 0001, n 1=365, n 2=215)$ and a $t$-test $(t=-6 \cdot 0, p<0 \cdot 0001, \mathrm{df}=578)$. In contrast,

Table 4 Summary of the results obtained from Kolmogorov-Smirnov tests upon comparisons of trait types within randomly generated data sets. The number given represents the number of tests (out of 25) which fell into a given significance level. For example, comparisons between life history and morphological traits yielded a $D_{\max }$ which was significant at $p<0 \cdot 0001$ for 25 of the 25 randomly generated data sets

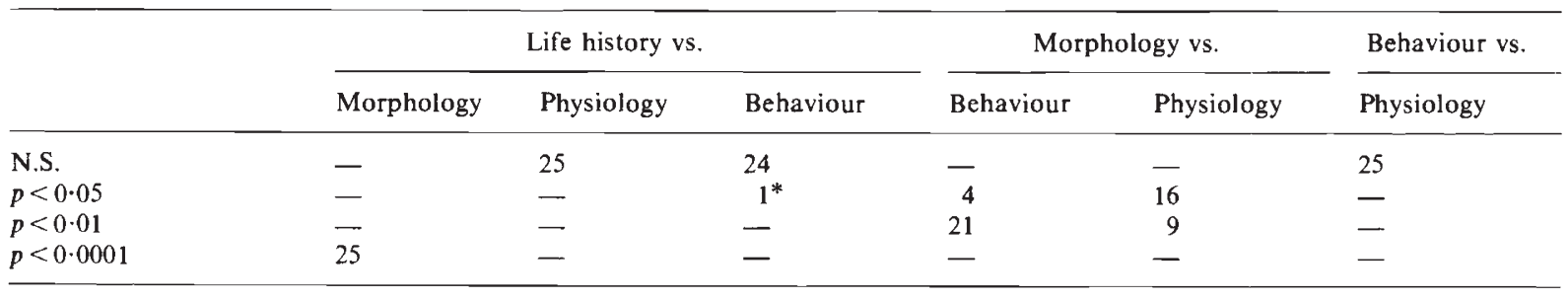

* Contrary to results obtained using medians.

N.S. = Not significant. 
Table 5 Within study comparison of traits. Estimates represent median values for trait. Sample sizes are given in parentheses. Paired comparison $t$-test: $D=-0.15$, S.E. $=0.061, t=-2 \cdot 3, p=0.038$. Wilcoxon's signed rank test: sum of negative ranks $=-88$, sum of positive ranks $=17 ; p=0.012$. Sign test: $p=0.029$

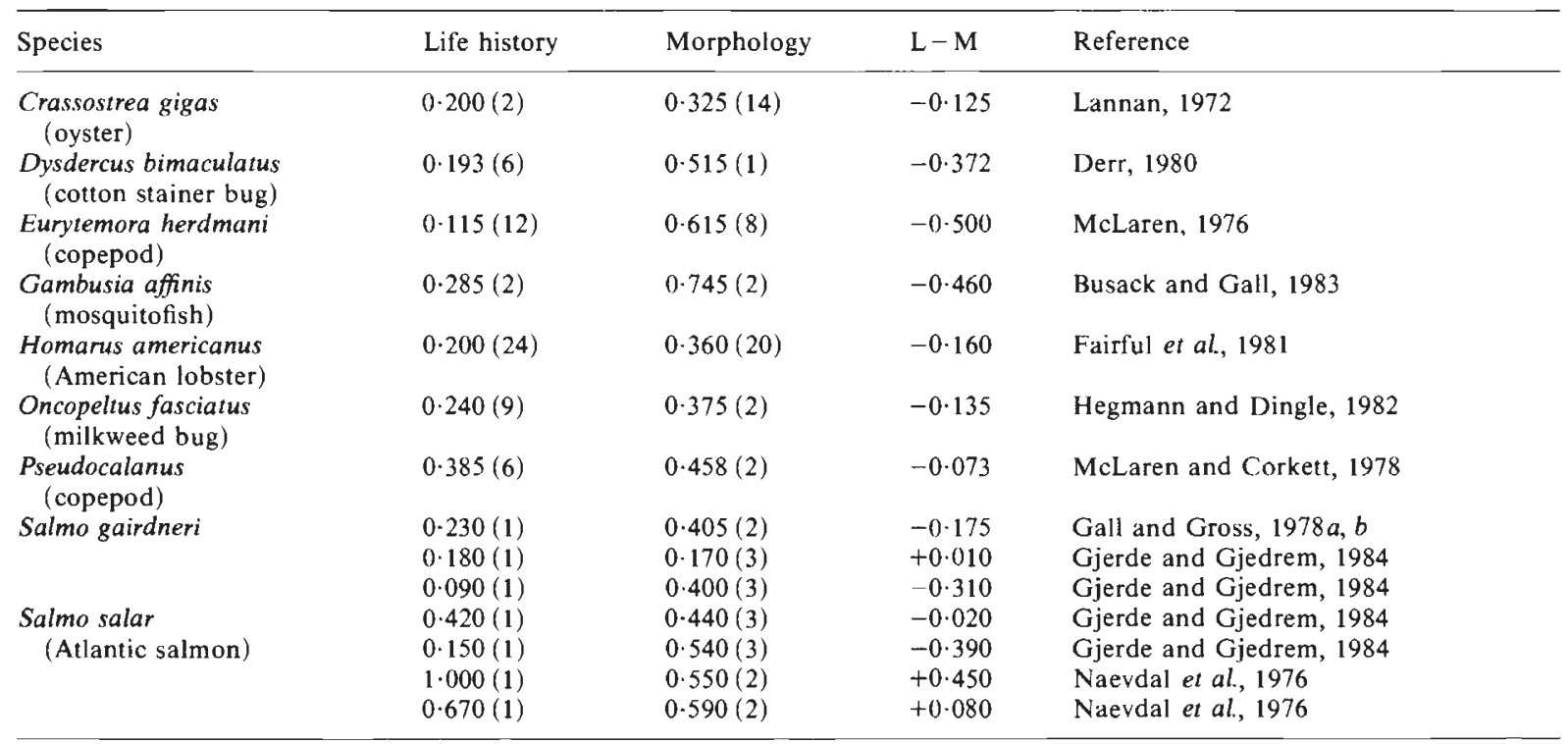

neither the mean nor the cumulative distribution of life history traits were significantly different between ectotherms and endotherms (fig. 5 ; $t$-test $t=-1 \cdot 63, p>0 \cdot 1, \mathrm{df}=345$; Kolmogorov-Smirnov $D_{\max }=0.37, p>0.05$ ), although the medians were found to be significantly different (Mann-Whitney U-test: $z=2 \cdot 81, p<0.005, n 1=333, n 2=14)$. The statistical analysis of comparisons between invertebrates and vertebrates (fig. 5) yielded insignificant results for both life history traits ( $t$-test $t=$ $0 \cdot 76, p>0 \cdot 4, \mathrm{df}=345$; Mann-Whitney U-test $z=$ $-1 \cdot 16, p>0 \cdot 25, n 1=211, n 2=136$; KolmogorovSmirnov $\left.D_{\max }=0.15, p>0.05\right)$, and morphological traits ( $t$-test $t=1 \cdot 2, p>0 \cdot 2, \quad \mathrm{df}=578$; Mann-Whitney U-test $z=-1 \cdot 7, p>0 \cdot 1, n 1=$ $108, n 2=472$; Kolmogorov-Smirnov $\quad D_{\max }=$ $0 \cdot 14, p>0 \cdot 05)$.

\section{DISCUSSION}

The notion that traits closely associated with fitness will generally posses lower heritabilities than more distantly related traits, is supported by all segments of our analysis. Our findings extend further support to the views of Fisher $(1930,1958)$ and Falconer $(1960,1981)$ concerning the nature of genetic variation within natural populations.

The ranking of trait types that we obtained for animals in general is consistent with that reported for Drosophila (Roff and Mousseau, 1987).
However, the estimated means for each category of trait differed dramatically. The mean $( \pm 1$ S.E. $)$ heritability values for morphological, life history, and behavioural traits in Drosophila (Roff and Mousseau 1987) were $0 \cdot 32( \pm 0 \cdot 02), 0 \cdot 12( \pm 0 \cdot 02)$, and $0.18( \pm 0.03)$ as opposed to $0.46( \pm 0.004)$, $0 \cdot 26( \pm 0 \cdot 01)$, and $0 \cdot 30( \pm 0.03)$ for animals in general (excluding Drosophila). This difference is consistent with the results we obtained from our comparison of ectothermic and endothermic organisms (see table 6), and may be related to the close association between life history traits and body size in many ectotherms (Kusano, 1982; Peters, 1983; Roff, 1981, 1984, 1986a).

Our results show that behavioural and physiological traits have heritabilities more like those of life history traits than those of morphological traits. One interpretation of this finding might be that physiological and behavioural traits are subject to constraints similar to those thought to influence fitness traits. In addition, this discovery supports Falconer's (1981) suggestion that physiological traits generally possess heritabilities intermediate between life history and morphological traits, and Lee and Parsons' (1968) contention that behaviou ral traits will usually be subject to stabilising selection. However, the magnitude of the average heritabilities of these traits suggests that significant genetic variance is maintained within most natural populations, even for traits closely affiliated with fitness. 


\section{LIFE HISTORY}
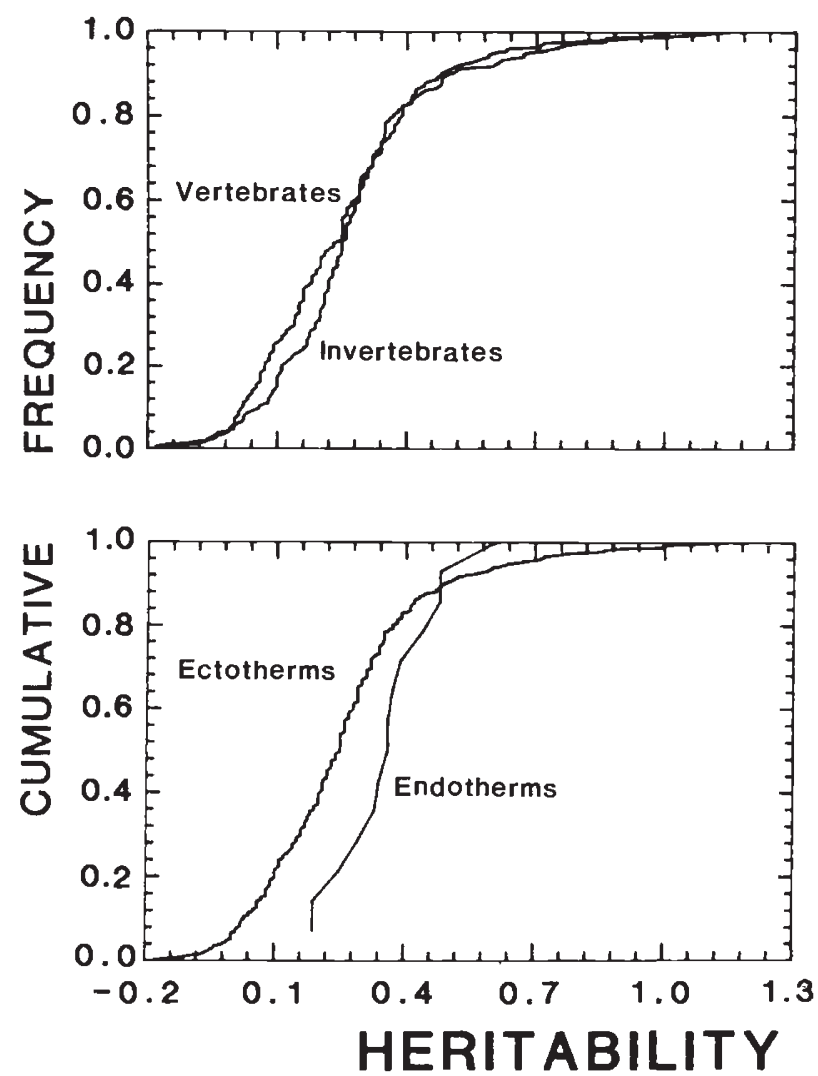

MORPHOLOGY
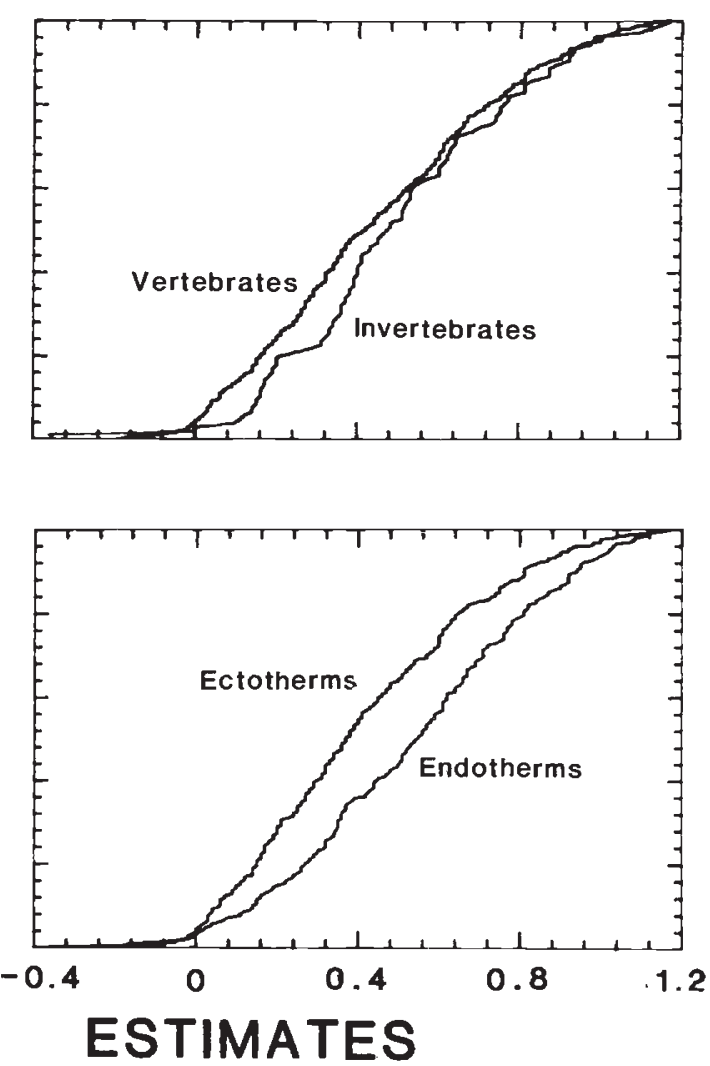

Figure 5 A comparison of the cumulative frequency distributions of ectotherms versus endotherms and vertebrates versus invertebrates for the heritability of life history and morphological traits. Note that data points are joined by straight lines.

Table 6 A comparison of the relative frequencies of heritability estimates. The ectotherm and endotherm data are from this study and are based upon the median by trait data set. The Drosophila data are derived from Roff and Mousseau (1987) and is based upon the median by study data set

\begin{tabular}{|c|c|c|c|c|c|c|}
\hline & \multirow{2}{*}{$\begin{array}{l}\text { \# of } \\
\text { estimates }\end{array}$} & \multicolumn{5}{|c|}{ Heritability Estimate } \\
\hline & & $<20 \%$ & $20-40 \%$ & $40-60 \%$ & $60-80 \%$ & $>80 \%$ \\
\hline \multicolumn{7}{|c|}{ Behaviour } \\
\hline Drosophila & $n=38$ & $68 \cdot 4$ & $18 \cdot 4$ & $7 \cdot 9$ & $5 \cdot 3$ & 0 \\
\hline Ectotherms & $n=16$ & 13 & 38 & 25 & 25 & 0 \\
\hline Endotherms & $n=9$ & 44 & 22 & 22 & 0 & 11 \\
\hline \multicolumn{7}{|c|}{ Life history } \\
\hline Drosophila & $n=20$ & 80 & 20 & 0 & 0 & 0 \\
\hline Ectotherms & $n=71$ & $39 \cdot 4$ & $47 \cdot 9$ & $8 \cdot 5$ & $2 \cdot 8$ & $1 \cdot 4$ \\
\hline Endotherms & $n=8$ & 0 & 50 & $37 \cdot 5$ & $12 \cdot 5$ & 0 \\
\hline \multicolumn{7}{|c|}{ Morphology } \\
\hline Drosophila & $n=67$ & $16 \cdot 4$ & $58 \cdot 2$ & $25 \cdot 4$ & 0 & 0 \\
\hline Ectotherms & $n=88$ & $19 \cdot 3$ & $26 \cdot 1$ & $23 \cdot 9$ & $15 \cdot 9$ & $14 \cdot 8$ \\
\hline Endotherms & $n=52$ & $13 \cdot 5$ & $17 \cdot 3$ & $23 \cdot 1$ & $28 \cdot 8$ & $17 \cdot 3$ \\
\hline
\end{tabular}


There are many factors which may be responsible for the maintenance of genetic variance of fitness characters. The rate of origin of variation by mutation alone may be sufficient to maintain substantial additive genetic variance within natural populations (Lande, 1976; Turelli, 1984). Heterozygote advantage (Falconer, 1981), frequency dependent selection (Bulmer, 1980), variable selection in heterogeneous environments (Ewing, 1979), diversifying selection (Thoday, 1972), and migration (Felsenstein, 1976) have been proposed as possible mechanisms for the sustenance of genetic variation. Also, significant heritabilities for fitness characters are not inconsistent with zero additive genetic variance in fitness given negative genetic correlations between fitness components (the antagonistic pleiotropy hypothesis). Much support has been generated for this hypothesis (e.g., Luckinbill et al., 1984; Rose, 1982, 1984; Rose and Charlesworth, 1981; Service and Rose, 1985); however others (e.g., Bell, 1984a, 1984b; Giesel, 1986; Murphy et al., 1983; Stearns, 1983) have challenged its generality.

In conclusion, much of what has been generally accepted in the evolutionary literature concerning patterns of genetic variance in natural populations is verified by this study; fitness components do indeed generally possess lower heritabilities than traits believed to be unconnected to fitness. However, the mechanisms by which the high observed heritabilities of fitness components are maintained remains unclear.

Acknowledgements This research was supported in part by a McConnell Memorial Fellowship to T.M. and by NSERC operating grant A7764 to D.R. We thank B. Charlesworth, A. Morin, V. Koufopanous, D. Fairbairn, and an anonymous referee for many helpful comments and discussions, and $\mathrm{H}$. Preston for special assistance. We extend our appreciation to the staff of the Botany-Genetics Library of McGill University for their patience and invaluable help in locating many references.

\section{REFERENCES}

ARNOL1, S. J. 1981. Behavioural variation in natural populations. I. Phenotypic, genetic and environmental correlations between chemoreceptive responses to prey in the garter snake, Thamnophis elegans. Evolution, 35, 489-509.

AULSTAD, D., GJEI)REM, T. ANi) SKJERVOLD, H. 1972. Genetic and environmental sources of variation in length and weight of rainbow trout (Salmo gairdneri). J. Fish. Res. Bd. Canada, 29, 237-241.

AYLLS, G. B. 1975. Influence of the genotype and the environment on growth and survival of rainbow trout (Salmo gairdneri) in central Canadian aquaculture lakes. Aquaculture, $6,181-188$.
AYRES, F. AND ARNOI.D, S. 1983. Behavioural variation in natural populations. IV. Mendelian models and heritability of a feeding response in the garter snake, Thamnophis elegans. Heredity, 51, 405-413.

BEATSON, R. 1976. Environmental and genetic correlates of disruptive coloration in the water snake. Evolution, 30, 241-252.

BELL, G. 1984a. Measuring the cost of reproduction. I. The correlation structure of the life table of a plankton rotifer. Evolution, 38, 300-313.

BELL, (i. 1984b. Measuring the cost of reproduction. II. The correlation structure of the life tables of five freshwater invertebrates. Evolution, 38, 314-326.

BLANC, J. M., CHEVASSUS, B. AND BERGOT, P. 1979. Determinisme genetique du nombre de coeca pyloriques chez la Truite faria (Salmo trutta, Linne) et la truite arcenciel. III. Effect du genotype et de la taille des oeufs sur la realisation du caractere chez la truite fario. Ann. Genet. Sel. Anim., 11, 93-103.

BOAG, P. T. 1981. Morphological Variation in the Darwin's Finches (Geospizinae) of Daphne Major Island, Galapagos. Ph.D. Dissertation, McGill University.

BOAG, P. T. 1983. The heritability of external morphology in Darwin's finches on Isla Daphne Major, Galapagos. Evolution, 37, 877-894.

BOAC, I'. T. AND GRANT, P. R. 1978. Heritability of external morphology in Darwin's finches. Nature, 274, 793794.

BONI)ARI, K. 1983. Response to bidirectional selection for body weight in channel catfish. Aquaculture, 33, 73-81.

BRADLEY, B. 1982. Models for physiological and genetic adaptation to variable environments. In Dingle, $\mathrm{H}$. and Hegmann, H. (eds.). Evolution and Genetics of Life Histories. Springer-Verlag, New York.

BRODY, T., WOHLFARTH, (3., HULATA, G. AND MOAV, R. 1981. Application of electrophoretic genetic markers to fish breeding. IV. Assessment of breeding value of full-sib families. Aquaculture, 24, 175-186.

BROOK, M. DE L. 1977. The Breeding Biology of the Manx Shearwater. Ph.D. Thesis, Oxford.

BROOKER, R., LHHMAN, R., HEIMBUCH, R. AND KIDD, K. 1981. Hand usage in a colony of Bonnett monkeys, Macaca radiata. Behav. Genet., 11, 49-56.

BRYANT. E. 1977. Morphometric adaptation of the house fly, Musca domestica in the United States. Evolution, 31,580596.

BRYANT, I: AND TURNER, C. 1978. Comparative morphometric adaptation of the housefly and the face fly in the United States. Evolution, 32, 759-770.

BULL, J., VOGT, R. AND BULMER, M. 1981. Heritability of sex ratio in turtles with environmental sex determination. Evol ution, 36, 333-341.

BUlmir, M. 1980. The Mathematical Theory of Quantitative Genetics. Clarendon Press, Oxford.

BUSACK, C. 1983. Four generations of selection for high 56 day weight in the mosquitofish (Gambusia affinis). Aquaculture, 33, 83-87.

BUSACK, C AND C;ALI, G. 1983. An initial description of the quantitative genetics of growth and reproduction in the mosquitofish. Aquaculture, 32, 123-140.

CADE, W. H. 1981. Alternative male strategies, genetic differences in crickets Gryllus integer. Science, 212, 563-564.

C:AlDWELL, R. AND HEGMANN, J. 1969. Heritability of flight duration in the milkweed bug Lygaeus kalmii. Nature, 223, 91-92.

CHARIESWOR'TH, B. 1987. The Heritability of Fitness. Dahlem Workshop on Sexual Selection. In press. 
CHERNOKOZHEYA, I. 1983. The maternal and paternal shares in the heritability of muscle heat resistance of tadpoles at different rearing temperatures. Tsitologiia, 25, 206-210.

CHEVASSUS, B. 1976. Varibilite et heritabilite des performances de croissance chez la truite arc-en-ciel (Salmo gaidneri, Richardson). Ann. Genet. Sel. Anim., 8, 273-283.

CHEVERUD, J. 1981. Variation in highly and lowly heritable morphological traits among social groups of the rhesus macaque on Cato Satiago. Evolution, 35, 75-83.

ClARKE, B., HORSLEY, A. W. AND PARKIN, D. T. 1978. Genetic variation and natural selection in pulmanate molluscs. In Fretter, V. and Peake, J. (eds.). Pulamonates. Academic Press, London.

COLLINS, A. M., RINDERER, T. E., HARBO, J. R. AND BROWN, M. A. 1984. Heritabilities and correlations for several characters in the honey bee Apis mellifera. J. Heredity, 75, $135-140$.

COOK, L. M. 1965. Inheritance of shell size in the snail Arianta arbustorum. Evolution, 19, 86-94.

CRAMER, S. AND MCINTYRE, J. 1975. Heritable resistance to gas bubble disease in the fall chinook salmon, Oncorhynchus tshawytscha. Fish. Bull., 73, 934-938.

DAWSON, P. S. 1975. Directional versus stabilizing selection for development time in natural and laboratory populations of flour beetles. Genetics, 80, 773-783.

DERR. J. 1980. The nature of variation in life history characters of Dysdercus bimaculatus, a colonizing species. Evolution, $34,548-557$.

DHONDT, A. 1982. Heritability of blue tit tarsus length from normal and cross-fostered broods. Evolution, 366, 418419.

DINGLE, H., BROWN, C. K. AND HEGMANN, J. P. 1977. The nature of genetic variance influencing photoperiodic diapause in a migrant insect, Oncopeltus fasciatus. Amer. Natur., 111, 1047-1059.

DINGLE, H., BLAKELY, N. AND MILLER, E. 1980. Variation in body size and flight performance in milkweed bugs. Evolution, 34, 371-385.

DINGLE, H., BLAU, W., BROWN, C. AND HEGMANN, J. P. 1982 Population crosses and the genetic structure of milkweed bug life histories. In Dingle, $\mathrm{H}$. and Hegmann, J. P. (eds.). Evolution and Genetics of Life Histories. Springer-Verlag, New York.

DOYLE, R. W. 1974. Choosing between darkness and light: the ecological genetics of photic behavior in planktonic larva of Spirorbis borealis. Marine Biology, 25, 311-317.

DUHRKOPF, R. AND YOUNG, S. 1979. Some consequences of selection for fast and slow recovery from the larval alarm reaction in Aedes aegypti. Theor. Appl. Genet., 55, 263-268.

DUNHAM, R. AND SMITHERMAN, R. 1983. Response to selection and related heritability for body size in three strains of channel catfish grown in earthen ponds. Aquaculture, $33,89-96$.

EBERT, P. AND HYDE, J. 1976. Selection for agonistic behavior in wild female Mus musculus. Behav. Genet., 6, 291-304.

EL-IBIARY, H. M. AND JOYCE, J. A. 1978. Heritability of body traits, dressing weight and lipid content in channel catfish. J. Anim. Sci., 47, 82-88.

ENGLERT, D. C. AND BELL, A. E. 1970. Selection for time of pupation in Tribolium casteneum. Genetics, 64, 541.

EWING, E. 1979. Genetic variation in a heterogeneous environment. VII. Temporal and spatial heterogeneity in infinite populations. Amer. Natur., 114, 197-212.

FAIRFULL, R., HALEY, L. AND CASTELL, J. 1981. The early growth of artificially reared American lobsters. Part 1: Genetic parameters within environments. Theor. Appl. Genet., 60, 269-273.
FALCONER, D. S. 1960. Introduction to Quantitative Genetics. Oliver and Boyd, London.

FALCONER, D. S. 1981. Introduction to Quantitative Genetics, Second edition. Longman, New York.

FELSENSTEIN, J. 1976. The theoretical population genetics of variable selection and migration. Ann. Rev. Genet., 10, 253-280.

FERRARI, J. A., TAYLOR, C. E., GEORCHIOU, G. P. AND LAGUMES, A. 1982. Selection with several insecticides in the mosquito Culex quinquefasciatus. Genetics, 100, 523524.

FINDLEY, C. AND COOKE, F. 1982. Breeding synchrony in the lessor snow goose. I. Genetics and environmental components of hatch date variability and their effects on hatch date synchrony. Evolution, 36, 342-351.

FINDLEY, C. AND COOKE, F. 1983. Genetic and environmental components of clutch size variance in a wild population of lessor snow geese. Evolution, 37, 724-734.

FINLEY, L. AND HALEY, L. 1983. The genetics of aggression in the juvenile American lobster, Homerus americanus. Aquaculture, 33, 135-139.

FISHER, R. A. 1930. The Genetical Theory of Natural Selection. Clarendon Press, Oxford.

FISHER, R. A. 1958. The Genetical Theory of Natural Selection, Second edition. Dover Publications, New York.

FLUX, J. E. C. AND FLUX, M. M. 1982. Artificial selection and gene flow in wild starlings, Sturnus vulgaris. Naturwissenschaften, 69, 96-97.

GALL, G. A. E. 1971. Replicated selection for 21-days pupa weight of Triboluim castaneam. Theor. Appl. Gen., 41, 164173.

GALL, G. A. E. 1975. Genetics of reproduction in domesticated rainbow trout. J. Anim. Sci., 40, 19-28.

GALL, G. A. E. AND GROSS, S. J. 1978a. Genetic studies of growth in domesticated rainbow trout. Aquaculture, 13, 225-234.

GALL, G. A. E. AND GROSS, S. J. 1978b. A genetic analysis of the performance of three rainbow trout broodstocks. Aquaculture, $15,113-127$.

GARNETT, M. 1981. Body size, its heritability and influence on juvenile survival among great tits. Ibis, 123, 31-41.

GIESEL, J. T. 1986. Genetic correlation structure of life history variables in outbred wild Drosophila melanogaster: effects of photoperiod regime. Amer. Nat., 128, 593-603.

GJERDE, B. 1981. Genetic variation in production traits of Atlantic salmon and rainbow trout. 32nd Annual Meeting of the European Association for Annual Production, 31 August-3 September 1981, in Zagreb, Yugoslavia, Paper IV-15.

GJERDE, B. 1982. Genetic variation in production traits of Atlantic salmon and rainbow trout. Ann. Genet. Sel. Anim., $14,113$.

GJERDE, B. AND GJEDREM, T. 1984. Estimates of phenotypic and genetic parameters for carcass traits in Atlantic salmon and rainbow trout. Aquaculture, 36, 97-110.

GJEDREM, T. AND AULSTAD, D. G. 1974. Selection experiments with salmon. I. Differences in resistance to vibrio disease of salmon parr (Salmo salar). Aquaculture, 3, 51-59.

GLUSHANKOVA, M. A. 1982. The evaluation of heritability of the grass frog aldolase and actomysin activities and heat resistence. Tsitologiia, 24, 960-964.

GOODING, R. AND HOLLEBONE, J. 1976. Heritability of adult weight in the tsetse fly. Experientia, 32, 1507-1508.

GRANT, P. R. 1981. Patterns of growth in Darwin's finches. Proc. Roy. Soc. Lond. B., 212, 403-432.

GRANT, P. R. 1983. Inheritance of size and shape in a small population of Darwin's finches. Proc. Roy. Soc. Lond. B., $220,219-236$ 
GREENWOOD, P., HARVEY, P. AND PERRINS, C. 1979. The role of dispersal in the great tit (Parus major): the causes, consequences and heritability of natal dispersal. J. Anim. Ecol., 48, 123-142.

GUNNES, K. AND GJEDREM, T. 1978. Selection experiments with salmon. IV. Growth of Atlantic salmon during two years in the sea. Aquaculture, 15, 19-33.

GUNNES, K. AND GJEDREM, T. 1981. A genetic analysis of body length and weight in rainbow trout reared in sea water for 18 months. Aquaculture, 24, 161-174.

HAGEN, D. 1973. Inheritance of numbers of lateral plates and gill rakers in Gasterosteus aculeatus. Heredity, 30, 303-312.

HAGEN, D. AND BLOUW, D. 1983. Heritability of dorsal spines in the fourspine stickleback (Apeltes quadracus). Heredity, $50,275-281$

HALlibuRTON, R. AND GALL, G. 1981. Disruptive selection and assortive mating in Tribolium casteneum. Evolution, 35, 829-843.

HEGMANN, J. AND DINGLE, H. 1982. Phenotypic and genotypic covariance structure in milkweed bug life history traits. In Dingle, H. and Hegmann, J. (eds.). Evolution and Genetics of Life Histories. Springer-Verlag, New York.

HEWITT, J. ANI FULKER, D. 1983. Using the triple test cross to investigate the genetics of behavior in wild populations. II. Escape-avoidance conditioning in Rattus norvegicus. Behav. Genet., 13, 1-15.

HIGHTON, R. 1960. Heritability of geographic variation in trunk segmentation in the red-backed salamander, Plethodon cinereus. Evolution, 14, 351-360.

HILLLESHEIM, E. 1984. Heritability of physiological characters of the Cape honeybee Apis mellifera capensis. Apidologie, $15,271-273$

HOLM, M. ANID NAEVDAL, G. 1978. Quantitative genetic variation in fish-its significance for salmonid culture. In Battaglia, B. and Beardmore, J. (eds.). Marine Organisms, Genetics, Ecology, and Evolution. Plenum Press, New York.

HOLTZER, T. O., BRADLEY, J. R., JR. AND RABB, R. L. 1976. Geographic and genetic variation in time required for emergence of diapausing Heliothis zea. Ann. Ent. Soc. Amer., 69, 261-265.

HYDE, J. AND SAWYER, T. 1980. Selection for agonistic behavior in wild female mice. Behav. Genet ., 10, 349-359.

IMURA, O. 1980. The color variation in larvae of Ephestria kuehniella (Lepidoptera Phycitdae). I. On the inheritance of colour variation. Konchu, 48, 248-258.

JONES, P. J. 1973. Some Aspects of the Feeding Ecology of the Great Tit, Parus major L. Ph.D. Thesis, Oxford.

KANIS, E., REFSTIE, T. AND GJEDREM. T. 1976. A genetic analysis of egg, alevin, and fry mortality in salmon, sea trout, and rainbow trout. Aquaculture, 8, 259-268.

KINCAID, H., BRIDGES, W. AND VON I.IMBACH, B. 1977. Three generations of selection for growth rate in fall spawning rainbow trout. Trans. Am. Fish. Soc., 106, 621-628.

KINGHORN, B. 1983a. Genetic variation in food conversion efficiency and growth in rainbow trout. Aquaculture, 32, $141-155$.

KINGHORN, B. $1983 b$. A review of quantitative genetics in fish breeding. Aquaculture, 31, 283-304.

KIRPICHNIKOV, V. S. 1981. Genetic Basis of Fish Selection. Springer-Verlag, New York.

KLUPP, R. 1979. Genetic variance of growth in rainbow trout (Salmo gairdneri). Aquaculture, 18, 115-122.

KUSANO, T. 1982. Postmetamorphic growth, survival, and age at first reproduction of the salamander, Hynobius nebulosus tokyoensis Tago in relation to a consideration of the optimal timing of first reproduction. Res. Pop. Ecol. (Japan), 24, 329-344.
LANDE, R. 1976. The maintenance of genetic variability by mutation in a polygenic character with linked loci. Genet. Res. Camb., 26, 221-235.

LANNAN, J. E. 1972. Estimating heritability and predicting response to selection for the Pacific oyster, Crassostrea gigas. Proc. Natn. Shell-Fish Ass., 62, 62-66.

LEE, B. T. O. AND PARSONS, P. A. 1968. Selection, prediction and response. Bio. Rev., 43, 139-174.

LISSSELS, C. M. 1982. Some Causes and Consequences of Family Size in the Canada Goose, Branta canadensis. Ph.D. Thesis, Oxford.

LIN, C. Y., PEVZNIR, I. ANI) FRIARS. G. W. 1979. Experimental investigations of errors of heritability estimates in index selection. Can. J. Genet. Cytol., 21, 303-308.

LINDER, D., SUMARI, O., NYHOLM,K. ANI SIRKKOMAA, S 1983. Genetic and phenotypic variation in production traits in rainbow trout strains and strain crosses in Finland. Aquaculture, 33, 129-134.

LINIDROTH, A. 1972. Heritability estimates of growth in fish. Aquilo Ser. Zool., 13, 77-80.

LUCKINBILI, I. S., ARKING, R., CLARE, M. J., CIROCCO, W. C. AND BUCK, S. A. Selection for delayed senescence in Drosophila melanogaster. Evolution, 38, 996-1003.

I.YNC:H, $\therefore$ AND SULZBACH, D. 1984. Quantitative genetic analysis of temperature regulation in Mus musculus. II. Diallel analysis of individual traits. Evolution, 38, 527-540.

MALECHA, S. R., MASUNO, S. AND ONIZUKA, D. 1984. The feasibility of measuring the heritability of growth variation in juvenile freshwater prawns Macrobrachium rosenbergii. Aquaculture, 38, 347-364.

MCINTYRE, J. AND AMEND, D. 1978. Heritability of tolerance for infectious necrosis in sockeye salmon. Trans. Am. Fish. Soc., 107, 305-308.

MCKAY, L. R., FRIARS, G. W. AND IHSSEN, P. E. 1984. Genotype $X$ temperature interactions for growth of rainbow trout. Aquaculture, 41, 131-140.

MCLAREN, I. 1976. Inheritance of demographic and production parameters in the marine copepod, Eurytemora herdmani. Biol. Bull., 151, 200-213.

MCLAREN, I. AND CORKETT, C. 1978. Unusual genetic variation in body size, development times, oil storage, and survivorship in the marine copepod Pseudocalanus. Biol. Bull., 155, 347-359.

MCWIRTER, K. 1969. Heritability of spot number in scillonian strains of the meadow brown butterfly (Maniola jurtina). Heredity, 24, 314-318.

MILNE, C. P. ANI FRIARS, G. W. 1984. An estimate of the heritability of honeybee pupal weight. J. Hered., 75, 509. 510

Minvifi,L.e, F. ANI Gall, G. A. 1980. Artificial selection for 18 day pupa weight and opposing simulated natural selection in Tribolium casteneum. Theor. Appl. Genet., 56, 49-55.

MIT(HFI, OLDS, T. ANI) RUTLEDGE, J. J. 1986. Quantitative genetics in natural plant populations: a review of the theory. Amer. Natur., 127, 379-402.

MOAV, R. ANI) WoHLfaRTH, G. 1976. Two-way selection for growth rate in the common carp (Cyprinus carpio L.). Genetics, 82, 83-101.

MOLLER, D. AND NAEVDAL, G. 1973. Variasjner i yngelvekt hos laks og regbueaure. Fisken Havet, Ser. B, No. 3, 21 pp.

MOLLER, D., NAEVDAI, (i. HOI.M, M. AND LEROY, R. 1976. Variation in growth rate and sexual maturity in rainbow trout. In Pillay, T. V. and Dill, Wm. A. (eds.). Advances in Aquaculture. Fish News Books. Farnham, England.

MORRIS, R. AND FULTON, w. 1970. Heritability of diapause intensity in Hyphantria cunea and correlated fitness responses. Can. Ent., 102, 927-938. 
MURPHY, P. A., GIESEL, J. T. AND MANLOVE, M. N. 1983. Temperature effects on life history variation in Drosophila simulans. Evolution, 37, 1181-1192.

MURRAY, J. AND CLARKE, B. 1967. Inheritance of shell size in Partula. Heredity, 23, 189-198.

NAEVDAL, G., HOLM, M., MOLLER, D. AND OSTHUS, O. D. 1975. Experiments with selective breeding of Atlantic salmon. ICES C. M. 1975/M15, 9 pp.

NAEVDAL, G., HOLM, M., MOLLER, D. AND OSTHUS, O. D. 1976. Variation in growth rate and age at sexual maturity in Atlantic salmon. ICES C. M. $1976 / E, 40,10$ pp.

NAGY, A., CSANYI, V., BAKOS, J. AND HORVATH, L. 1980 Development of a short term laboratory system for the evaluation of carp growth in ponds. Bamidgeh, 32, 6-15.

NEWKIRK, G., HALEY, L., WAUCH, D. AND DOYLE, R. 1977. Genetics of larval and spat growth rate in the oyster. Mar. Biol., 41, 49-52.

OJANEN, M., ORELl, M. AND VAISANEN, R. 1979. Role of heredity in egg size variation in the great tit Parus major and the pied flycatcher. Ornis. Scand., 10, 22-28.

OLDROYD, B. AND MORAN, C. 1983. Heritability of worker characters in the honeybee Apis mellifera. Australian J. Biol. Sci., 36, 323-332.

OROzCO, F. 1976. A dynamic study of genotype environment interaction with egg laying of Tribolium casteneum. Heredity, 37, 157-171.

ORSKA, I. 1963. The influence of temperature on the development of meristic characters in Salmonidae. I. Temperature controlled variations of the number of vertebrae in Salmo irideus Gibb. Zool. Pol., 12, 309-339.

PANSERA, M. C. AND AROUJO, A. M. 1983. Distribution and heritability of red raylets in Heliconius eratophyllis (Lepidoptera, hyphalidae). Heredity, 51, 643-652.

PASHKovA, I. M. 1978. Changes in the paternal and maternal shares in the heritability of heat resistence of the body and muscles of Asellus aquaticus during heat acclimation. Tsitilogiya, 20, 1197-1202.

PERRINS, C. AND JONES, P. 1974. The inheritance of clutch size in the great tit. Condor, 76, 225-229.

PETERS, R. H. 1983. The Ecological Implications of Body Size. Cambridge University Press, New York

RAUSHER, M. D. 1983. Conditioning and genetic variation as causes of individual variation in the oviposition behavior of the tortoise beetle, Deloya guttata. Anim. Behav., 31, 743-747.

REAGAN, R. E. 1980. Heritabilities and genetic correlations of desirable commercial traits in channel catfish. Compl. Rep. Miss. Agric. For. Exp. Stn., Publ. by MAFES-MS (U.S.A.) (June 1980) pp. 4-5.

Reagan, R. E., Pardue, G. And eisen, E. 1976. Predicting selection response for growth of channel catfish. J. Heredity, 67, 49-53.

REFSTIE, T. 1980. Genetic and environmental sources of variation in body weight and length of rainbow trout fingerlings. Aquaculture, 19, 351-357.

REFSTIE, T. AND STEINE, T. 1978. Selection experiments with Salmon. III. Genetic and environmental sources of variation in length and weight of Atlantic salmon in the freshwater phase. Aquaculture, 14, 221-234.

REFSTIE, T., STEINE, T. AND GJEDRUM, T. 1977. Selection experiments with salmon. 11. Proportion of Atlantic salmon smoltifying at one year of age. Aquaculture, 10, 231-242.

RICKER, W. E. 1973. Linear regressions in fishery research. $J$. Fish. Res. Bd. Canada, 30, 409-434.

RIDDILL, B., LEGGETT, W. AND SAUNDERS, R. 1981. Evidence of adaptive polygenic variation between two populations of Atlantic salmon (Salmo salar) native to tributaries of the S.W. Miramichi River, N. B. Can. J. Fish. Aquat. Sci., $38,321-333$.

RINDER, T. E., COLlins, A. M. AND BROWN, M. A. 1983. Heritabilities and correlations of honeybee response to Nosema apis longevity and alarm response to isopentylacetate. Apidologie, 14, 79-86.

ROFF, D. A. 1981. On being the right size. Amer. Natur., 118, $405-422$.

ROFF, D. A. 1984. The evolution of life history parameters in teleosts. Can. J. Fish. Aquat. Sci., 41, 989-1000.

ROFF, D. A. 1986a. Predicting body size with life history models. Bioscience, 36, 316-323.

ROFF, D. A. 1986 b. The genetic basis of wing dimorphism in the sand cricket, Gryllus firmus and its relevance to the evolution of wing dimorphism in insects. Heredity, 57, 221-231

ROFF, D. A. AND MOUSSEAU, T. A. 1987. Quantitative genetics and fitness: Lessons from Drosophila. Heredity. 58, 103-118.

ROSE, M. R, 1982. Antagonistic pleiotropy, dominance and genetic variation. Heredity, 48, 63-78.

ROSE, M. R. 1984. Genetic covariation in Drosophila life history: Untangling the data. Amer. Nat., 123, 565-569.

ROSE, M. R. AND CHARLESWORTH, B. 1981. Genetics of life history in Drosophila melanogaster. 1. Sib analysis of adult females. Genetics, 97, 173-186.

RYMAN, N. 1972. An attempt to estimate the magnitude of additive genetic variation of body size in the guppy-fish Lebistes reticulatus. Hereditas, 71, 237-244.

RYMAN, N. 1973. Two-way selection for body weight in the guppy-fish, Lebistes reticulatus. Hereditas, 74, 239-246.

SAXTON, A., HERSHBERGER, W. AND IWAMOTO, R. 1984. Smoltification in the net pen culture of coho salmon: quantitative genetic analysis. Trans. Am. Fish. Soc., 113, 339-347.

SERVICE, P. M. AND ROSE, M. R. 1985. Genetic covariation among life history components: the effect of novel environments. Evolution, 39, 943-945.

SMISEK, J. 1979. Considerations of body conformation, heritability, and biochemical characters in genetic studies of carp in Czechoslovakia. Bull. VURH Vodnawy, 15, 3-6., Ref. Anim. Bredd. Abstr., 48, 302.

SMITH, J. AND DHONDT, A. 1980. Experimental confirmation of heritable morphological variation in a natural population of song sparrows. Evolution, 34, 1155-1158.

SMITH, J. AND ZACH, R. 1979. Heritability of some morphological characters in the song sparrows. Evolution, 33, 460-467.

SMITH, R. 1978. Selection for shuttle avoidance in wild Mus musculus. Behav. Genet., 8, 269-274.

SOKAL, R. R. AND ROHLF, F. J. 1981. Biometry, 2nd edition. Freeman, San Francisco, U.S.A.

SOlimAN, H. 1982. Directional and stabilizing selection for development time and correlated response in reproductive fitness in Tribolium casteneum. Theor. Appl. Genet., 63, 111-116.

SOLLER, M. AND BAR-COHEN, R. 1967. Some observations on the heritability and genetic correlation between honey production and brood area in the honeybee. J. Apic. Res., 6, 37-43.

STEARNS, S. C. 1983. The genetic basis of differences in lifehistory traits among six populations of mosquitofish ( $\mathrm{Gam}$ busia affinis) that shared ancestors in 1905. Evolution 37, 618-627.

SUMNER, F. B. 1918. Continuous and discontinuous variation and their inheritance in Peromyscus. Amer. Natur., 52, 177-288, 290-301, 439-454.

TAve, D. AND Smitherman, R. O. 1980. Predicted response to selection for early growth in Tilapia nilotica. Trans. Am. Fish. Soc., 109, 439-445. 
TEPIDINO, V., THOMPSON, R. AND TORCHIA, P. 1984. Heritability for size in the megachilid bee Osmia lignaria propinqua. Apidologie, 15, 83-88.

Thoday, J. 1972. Disruptive Selection. Proc. Roy. Soc. Lond. $B, 182,109-143$.

TURELLI, M. 1984. Heritable genetic variation via mutationselection balance: Lerch's zera meets the abdominal bristle. Theor. Pop. Theory, 25, 138-193.

UNDERHILL, I. 1968. Heritability of dorsal spot number and snout vent length in Rana pipiens. J. Heredity, 59, 235-240.

VAN NOODWIJK, A., VAN BALEN, J. AND SCHARLO(), W. 1980. Heritability of ecologically important traits in the great tit. Ardea, 68, 193-203.
VAN NOORI)WIIK, A., VAN BALEN, I. AND SCHARLOO, W. $1981 a$. Genetic variation in the timing of reproduction in the great tit. Oecologia, 49, 158-166.

VAN NOORDWIJK. A., KEIZER, L., VAN BAIEN, J. AND SC:HARLOO, W. 1981 b. Genetic variation in egg dimensions in natural populations of the great tit. Genetica, 55, 221 232.

VAN OORTMERSSEN, G. AND BAKKER, I. 1981. Artificial selection for short and long attack latencies in wild Mus musculus domesticus. Behav. Genet., 11, 115-126.

ZAWILSKI, A. 1972. Heritability of four morphological characters in honeybees (Apis mellifica mellifica L.). Genetica Polonica, 13, 41-49.

Appendix Listing of species, traits represented, and sources. $\mathrm{B}=$ behaviour, $\mathrm{L}=$ life history, $\mathrm{M}=$ morphology, and $\mathrm{P}=$ physiology.

\begin{tabular}{llllllll}
\hline Species & B & L & M & P & Reference
\end{tabular}

Invertebrates

Aedes aegypti

(mosquito)

Apis mellifera

(honeybee))

Apis mellifica

(honeybee)

\section{Arianta arbustorum}

(snail)

Asellus aquaticus

(isopod)

Cepaea nemoralis

(pulmonate)

Crassostrea virginica

(oyster)

C. gigas

(Pacific oyster)

Culex quinquefasciatus (mosquito)

Deloyala guttata

(tortoise beetle)

Dysdercus bimaculatus

(cotton stainer bug)

Ephestria kuehniella

(Mediteranean flour moth)

Eurytemora affinis (copepod)

E. herdmani

(copepod)

Glossina morsitans (tsetse fly)

Gryllus integer (field cricket)

Heliconius erato (butterfly)

Heliothis zea (corn earworm)

Homerus americanus (American lobster)

Hyphantria cunea

(fall webworm)

*

$*$

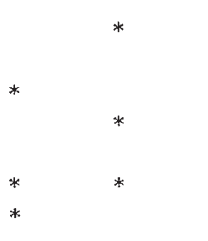

Duhrkopf and Young, 1979

Hillesheim, 1984

Collings et al, 1984

Milne and Friars, 1984

Oldroyd and Moran, 1983

Rinder et al., 1983

Soller and Bar-Cohen, 1967

Zawilski, 1972

Cook, 1965

* Pashkova, 1978

Clarke et al., 1978

Newkirk et al., 1977

Lannan, 1972

Ferrari et al., 1982

Rausher, 1983

Derr, 1980

Imura, 1980

* $\quad$ Bradley, 1982

McLaren, 1976

Gooding and Holebone, 1976

Cade, 1981

Pansera and Aroujo, 1983

* Holtzer et al., 1976

Fairfull et al, 1981

Finley and Haley, 1983

* $\quad$ Morris and Fulton, 1970 
Appendix continued

\begin{tabular}{|c|c|c|c|c|c|}
\hline Species & B & $\mathrm{L}$ & M & $\mathbf{P}$ & Reference \\
\hline $\begin{array}{l}\text { Lygaeus kalmii } \\
\text { (milkweed bug) }\end{array}$ & $*$ & & & & Caldwell and Hegmann, 1969 \\
\hline $\begin{array}{l}\text { Macrobrachium rosenbergii } \\
\text { (freshwater prawn) }\end{array}$ & & $*$ & & & Malecha et al., 1984 \\
\hline $\begin{array}{l}\text { Maniola jurtina } \\
\text { (meadow brown butterfly) }\end{array}$ & & & $*$ & & McWhirter, 1969 \\
\hline Musca domestica & & & $*$ & & Bryant, 1977 \\
\hline (house fly) & & & $*$ & & Bryant and Turner, 1978 \\
\hline Oncopeltus fasciatus & & $*$ & & & Dingle et al., 1977 \\
\hline \multirow[t]{3}{*}{ (milkweed bug) } & & & * & & Dingle et al., 1980 \\
\hline & & & & * & Dingle et al., 1982 \\
\hline & & $*$ & * & & Hegmann and Dingle, 1982 \\
\hline $\begin{array}{l}\text { Osmia lignaria } \\
\quad(\text { megachilid bee })\end{array}$ & & & * & & Tepedina et al., 1984 \\
\hline $\begin{array}{l}\text { Partula suturalis } \\
\quad \text { (snail) }\end{array}$ & & & $*$ & & Murray and Clarke, 1967 \\
\hline $\begin{array}{l}\text { P. taeniata } \\
\text { (snail) }\end{array}$ & & & * & & Murray and Clarke, 1967 \\
\hline $\begin{array}{l}\text { Pseudocalanus } \\
\quad \text { (copepod) }\end{array}$ & & $*$ & $*$ & & McLaren and Corkett, 1978 \\
\hline $\begin{array}{l}\text { Spirorbis borealis } \\
\quad \text { (polychaete worm) }\end{array}$ & $*$ & & & & Doyle, 1974 \\
\hline \multirow{8}{*}{$\begin{array}{l}\text { Tribolium casteneum } \\
\text { (flour beetle) }\end{array}$} & & * & & & Dawson, 1975 \\
\hline & & * & & & Englert and Bell, 1970 \\
\hline & & * & & & Gall, 1971 \\
\hline & & & $*$ & & Halliburton and Gall, 1981 \\
\hline & & $*$ & & & Lin et al., 1979 \\
\hline & & $*$ & & & Minivielle and Gall, 1980 \\
\hline & & $*$ & & & Orozco, 1976 \\
\hline & & $*$ & & & Soliman, 1982 \\
\hline
\end{tabular}

Fish

Apeltes quadracus (fourspine stickleback)

Coregonus lavaretus (whitefish)

Cyprinus carpio (common carp)

Gambusia affinis (mosquitofish)

Gasterosteus aculeatus (threespine stickleback)

Ictalurus punctatus (channel catfish)

Lebastes reticulatus (guppyfish)

Macropodus opercular

Oncorhynchus kisutch (coho salmon)

o. nerka (sockeye salmon)

O. tshawytscha (chinook salmon) Oryzias latipes Poecilia reticulata (guppy) 
Appendix continued

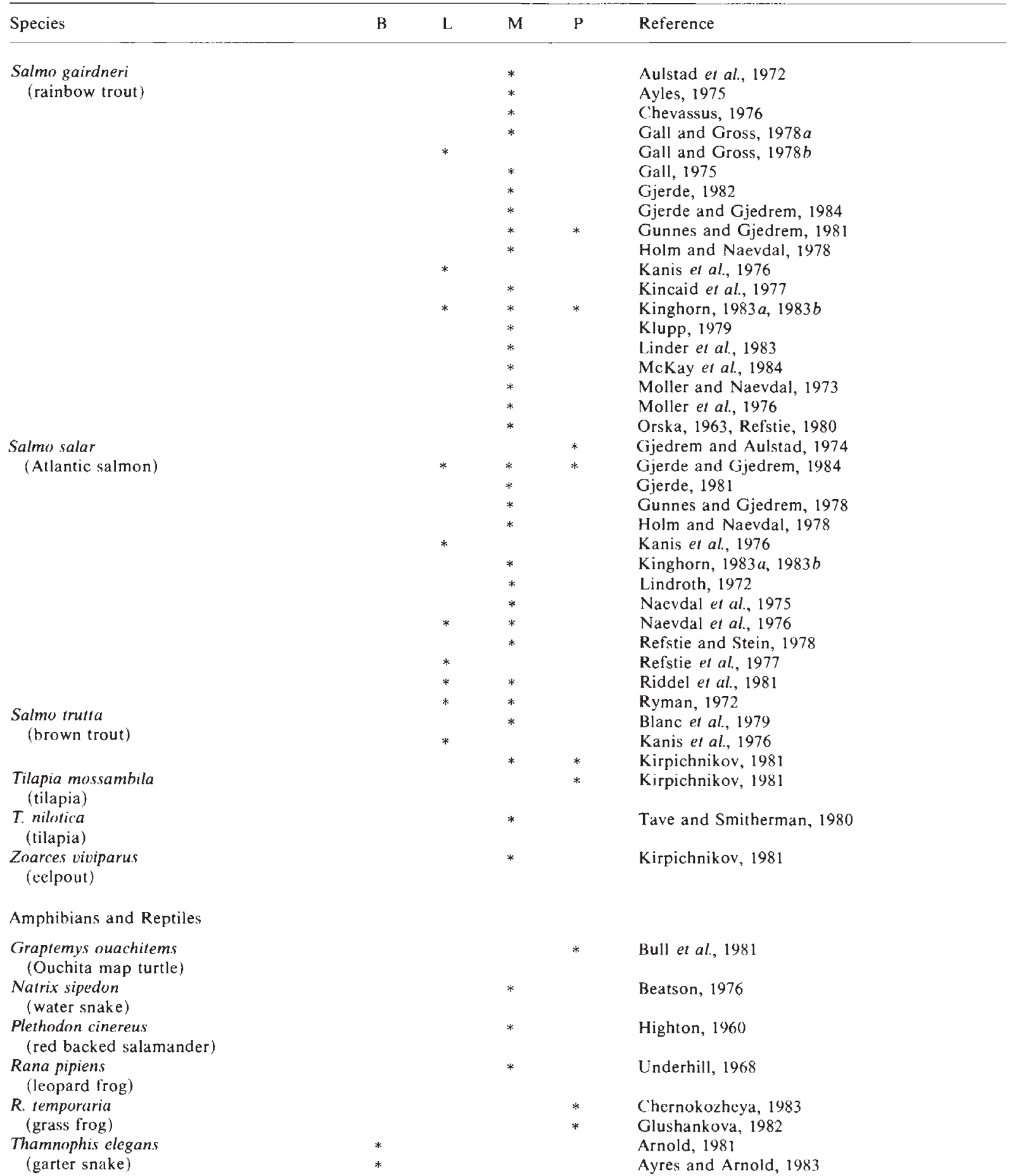

Birds

Anser caerulescens

(lesser snow goose) 
Appendix continued

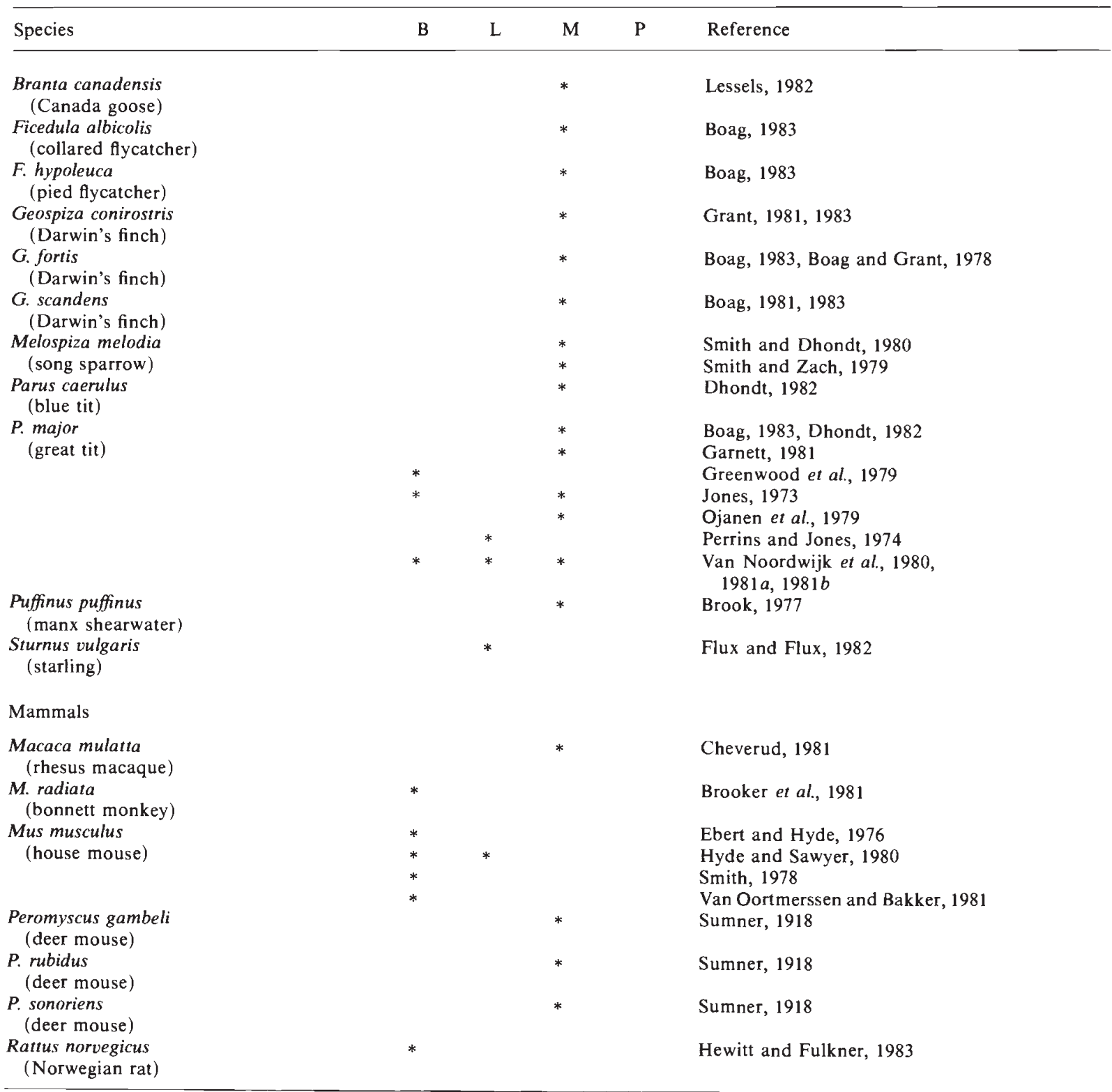

